JOURNAL OF

French and Francophone Philosophy
REVUE DE LA

philosophie française et de langue française

\title{
Letting-be: Dwelling, Peace and Violence in Ngugi wa Thiong'o's Petals of Blood
}

Grant Farred

Journal of French and Francophone Philosophy - Revue de la philosophie française et de langue française, Vol XXV, No 1 (2017) 10-26.

\author{
Vol XXV, No 1 (2017) \\ ISSN 1936-6280 (print) \\ ISSN 2155-1162 (online) \\ DOI $10.5195 /$ jffp. 2017.811 \\ www.jffp.org
}

\section{(c) EY-NC-ND}

This work is licensed under a Creative Commons Attribution-Noncommercial-No Derivative Works 3.0 United States License.

\section{ULIS D-Sunt}

This journal is operated by the University Library System of the University of Pittsburgh as part of its D-Scribe Digital Publishing Program, and is co-sponsored by the University of Pittsburgh Press 


\title{
Letting-be
}

\section{Dwelling, Peace and Violence in Ngugi wa Thiong'o's Petals of Blood}

\author{
Grant Farred
}

Cornell University

What is it to dwell?

Martin Heidegger, "Building Dwelling Thinking"

It is dwelling that allows mortals to initiate themselves in time and space. As such, dwelling constitutes the event of being. In his essay "Building Dwelling Thinking," Martin Heidegger stipulates that dwelling can only be achieved through harmonious relations among the constituents, earth, sky, mortals and gods ("divinities"), of the "fourfold." Heidegger writes, "To preserve the fourfold, to save the earth, to receive the sky, to await the divinities, to initiate mortals - this fourfold preserving is the simple essence of dwelling." 1 Initiating themselves in time and space is the great difficulty that the residents of Ilmorog, the remote village in postcolonial Kenya in which Ngugi wa Thiong'o's novel Petals of Blood is set, experience; in Petals of Blood, dwelling is what defines mortals' being.

In Petals of Blood, moments of dwelling are rare (and intensely rural), rendering Ngugi's iteration of postcolonial dwelling in a distinctly Heideggerian register. Ngugi's romanticized vision of rural life in postcolonial Africa as the only condition in which dwelling can be conceived echoes Heidegger's own romantic nostalgia for rural life in Germany - that mythic, architecturally perfect and environmentally constructed "farmhouse" that Heidegger so venerates. Heidegger's builder is acutely aware of the geographical vagaries of the place in which he - we have no doubt that it is a man who is at work here - builds this farmhouse; he takes care, in building, to account for the direction of the wind and the rain; he takes advantage of the protection offered by the mountains, and so on. This act of building is what it means to dwell, "thought essentially." The being of human beings is, as it were, secured by and is possible only through dwelling. 
In Ngugi's novel Heidegger's question "What is it to dwell?" serves to render the Kenyan postcolonial as a threat to being, registering Heidegger's question as the existentialist critique at the core of Petals of Blood. In Heidegger's essay "What is it to dwell?" assumes a range of forms, beginning with inquiries into the relationship between dwelling and, to take liberties here, the postcolonial, the conditions under which postcolonial conditions dwelling is possible, and, critically, whether it is possible to conceive of dwelling without violence. Or, in the terms of this essay, must dwelling and violence be thought together under the condition of "lettingbe?" The way in which this last question is posed suggests less an inquiry which retains in it always something tentative, a hint of uncertainty and openness to a different prospect - than a dire articulation. It seems, in our moment when the postcolonial state is burdened by "an epidemic of low expectations,"2 a moment dramatized by Ngugi in Petals of Blood when postcoloniality was still a first-generation political project, that it is indeed impossible to conceive of dwelling as a postcolonial letting-be that is without violence. But if the postcolonial condition is, to amend a phrase from Pierre Bourdieu's critique of the state, an almost "unthinkable object," then what Ngugi's novel makes immanent is the obvious determination to think dwelling as an intense complexity.

Petals of Blood begins from the premise that dwelling is best articulated as a desire for peace and oneness with the earth, if not the all of the fourfold. This essay proceeds in that spirit, and works in those terms (for the most part, because already there is reason enough to be skeptical of such a notion of dwelling) in the first section. What emerges, because of Ngugi's text itself, is the refiguring of dwelling as a mode of being that might properly be named "letting-be." This essay thus pivots on the tension between dwelling as the desire for peace (an entirely plausible, even laudable, ambition for the postcolonial project) and a critique of this desire as romanticization because every moment of peace invariably seems limned by the portent of violence; this essay negotiates, in short, between dwelling (peace) and letting-be, between dwelling as "monolingual" and polyvalent. It is a tension that is not, conceptually, resolved (perhaps because a resolution is, necessarily, impossible) but it is the conceptual difficulty that drives the essay.

To let-be is a mode of being in which everything, every aspect of life, is manifestly present. To let-be presupposes a radical openness to the fourfold - to the world - so that dwelling is best recognized as an intense understanding of how to be in the world, of what it means to be. In its radical openness, to let-be admits of everything in the world. Letting-be, then, is to know dwelling as living manifestly, to be fully "there" in the presence of peace (a rare occurrence in Ilmorog; but all of Ngugi's protagonists are in search of peace) as well as under conditions of violence inscribed in the "blood" of Ngugi's title. To let-be is to desire dwelling as the highest mode of peace, to struggle against violence (in its many 
manifestations), but it is also to know how to be in the midst of the violent struggle against violence that can never truly overcome that violence. To name violence as constitutive of dwelling is to understand dwelling as a properly political project. To dwell is, in these terms, to recognize - to think [Denken] - the violence (and the inclining toward peace) that is at the core of dwelling. That is, to achieve dwelling is/as nothing less than a violent struggle; a violent struggle with the self, with building [Bauen], with dwelling [Wohnen] itself; to let-be the violence that so animates the struggle for dwelling, that is at once so inimical of violence and so proximate to it.

\section{A rare moment: the oneness of the rural women and/with the earth}

A teacher without any real personal or professional prospects, Godfrey Munira arrives in old Ilmorog, a dusty, godforsaken (the pun is unavoidable) village in postcolonial Kenya with an aging population. (The youth and the young adults of Ilmorog have decamped, in significant numbers, to the city in search of greater economic opportunities and social pleasures.) Munira is alienated both from his family, a "refugee from a home where certain things were never mentioned" - in this "home," ruled over by his judgmental father, sex and desire were among the chief "unmentionables" to Munira's puritanically Christian wife - and the politics of postcolonial Kenya ("Any talk of colonialism made him uneasy"). ${ }^{3}$ As a Kenyan who did not participate in the war of liberation against British colonialism, the promise of a dwelling is what draws Munira to Ilmorog. 4 This is also true of Ngugi's other protagonists. Wanja (a former prostitute who becomes Abdulla's barmaid and later establishes herself as New Ilmorog's chief entrepreneur in the sex industry; she is also lover to both Munira and Karega), Abdulla (the former Mau Mau fighter who is crippled by the war against the British colonialists), and Karega (a young militant who was once Munira's prize pupil at New Ilmorog Primary), all come in search of peace; all of their various quests reveal dwelling as a complex interplay amongst peace, violence and interstitial moments that are neither peaceful nor violent.

Not surprisingly, Munira's understanding of dwelling turns on a just such an interplay between his remove (a superiority grounded in his education, the status afforded him as teacher; he stands aloft, but not alone in the political economy of village life) and the eroticized pleasure which the autochthony of rural Kenyan life gives him: "It was not only the high esteem in which the village held him: he cherished and was often thrilled by the sight of the women scratching the earth because they seemed at one with the green land."5 Ngugi's description of the oneness of mortals and the earth, the "women scratching the earth because they seemed at one with the green land," is nothing other than the transcription of Heidegger's dwelling fitted 
for a postcolonial landscape in which that essential oneness of the fourfold is under threat.

This oneness is itself saliently unprecedented for Munira, son of the Kenyan elite, and so the displaced schoolteacher is deeply affected by the presence of the peasant women tending the land. Munira is "thrilled by the sight of the women scratching the earth;" he is, such is the nature of his "thrill," envious of their autochthony, their ability to be "at one with the green land." This is the relationship of Gewohnte, embodying through their labor the history of their relationship to this land; one hears also in Heidegger's term gewöhnen, the practice of "getting used to," "getting accustomed to," "familiar with," which opens to the possibility of "habit" the regular usage of a thing, the tendency to perform this task again and again. It is this practice, this mode of inhabiting - of living in and with, and of course because of - the land that Munira must learn; in observing the "oneness" of the women with the green earth he is learning how to both appreciate (from a distance, albeit an enthralled distance) their autochthony and to be, in Heidegger's terms, their neighbor [Nachbar] - to be close to them, to imagine the possibility of emulating this relationship. Munira is confronting, through his watching, what it means to dwell (to be at peace, to be in oneness), to dwell through work, what it means to be near to, live in close proximity to, the other. ${ }^{6}$ For Ngugi (and no less for the Heidegger of the idyllic German farmhouse), dwelling is conceivable only as autochthony: It is rooted, unambiguously, in the earth, in the struggle to be one with the earth, to make the earth productive, to sustain mortals through engagement with the earth. In Petals of Blood, dwelling is grounded, terrestrial, with no possibility for autochtony. Dwelling, in this rendering, could not take place in, say, a space ship; dwelling is strictly an earthbound possibility and as such it is bound up in the difficulties - the politics - of letting-be.

There is, then, a certain nostalgia that grounds Ngugi (and Heidegger's) romanticism for rural life in sub-Saharan Africa (and rural Germany). Nostalgia in Jacques Derrida's "nostalgeric" sense, which designates that irrecoverable place from which the postcolonial self can never be untethered, from which it can never disarticulate itself; 7 and yet, it is to that selfsame place that the diasporized postcolonial can never return, that site of violence done to the self from which the self can never sever itself, that place of letting-be. In Petals of Blood the village of Ilmorog constitutes the autochthone. But the old Ilmorog is not New Ilmorog. The village that we might name the old Ilmorog is a name, an act of naming, haunted by mourning. New Ilmorog is that place which succeeds, through economic displacement, the old Ilmorog. This economic displacement, a process that involves capital investment, transforms the village into an industrial town; New Ilmorog thus marks the loss of rural life and, hence, autochthony. Etymologically speaking, "springing from the earth" (but also remaining felicitous to that grounding), the autochthone is the postcolonial 
mode of being that Ngugi endorses, an underwriting that opens onto the complications of letting-be where the autochthone is always in the presence of violence as much as it strives toward oneness (peace). As such, the autochthone stands in a fabulously puzzling relation to the fourfold. The autochthone at once underscores the rootedness in and of the earth and throws into question any notion of "transcendence;" Ngugi's autochthone would seem to resist any prospect that challenges or undermines the primacy of the earth. The autochthone cannot admit of a life - the act of living - that does not spring from the earth, that springing from the earth that holds Munira so in its thrall, the springing forth that seems to condense dwelling into being, and being into the letting-be violence/oneness of dwelling.

Held out in the act of Munira's observation is a different mode of being in postcolonial Kenya, a possibility previously unimaginable to him, a possibility enabled entirely by Ilmorog. The ultimate promise of the Nachbar is to provide the possibility of being in peace (to suspend, if even for a moment, the violence that marks dwelling): "ich bin, du bist, I am, you are." 8 To dwell is to be; to be is incline toward dwelling; to observe those who dwell, to be thrilled by their dwelling is to increase the likelihood of being. Heidegger asserts that "the manner in which we humans are on earth, is bauen, dwelling," directly linking building to dwelling and in so doing establishing a relationship of being to dwelling. ${ }^{9}$ There is a mutuality between Sein and bauen; a sharing, if you will, is established. ${ }^{10}$ It becomes, then, almost impossible to determine primacy. One cannot, plausibly, ask about which comes first: Sein or bauen? How, under these circumstances, is it possible to think Sein and bauen discretely? It becomes impossible to think one without the other, to think first one and then the other. All these inquiries must be posed in, and through, a single interrogative gesture.

It is only possible to be (we-all-are) when we dwell (bauen: when we build to dwell; when dwelling is the first condition for building). Watching from a distance, all the while drawn to it, drawn into it, this act of the Ilmorog women bauen is, in all probability unknown to him (and yet powerful in its sentience; in this case a sentience deriving from the nearness of the Nachbar, to the other in their familiarity, in their shared affinity for the land, for its history), at the affective base of Munira's thrill. (If, in Yogi Berra's memorable phrase, "You can observe a lot just by watching," then we can learn a great deal about both Ilmorog's political economy and Munira's remove from it "just by watching" Munira "observe" the women at work.) In crypto-psychological terms, bauen is the magnetic force that opens onto being. It is bauen that opens mortals to being, and it is toward Sein that Munira is being instructed through his observation of the women. To translate Munira's experience as a Yogi Berra truism: you can learn a lot about yourself, your desires, your rootedness or your alienation, (just) by observing others. 
It is within this philosophical framework that the women of Ilmorog are "building," ["Bauen"], are tending more than their crops. They are building, nurturing (caring for the land, caring what is to hand, caring for what it is their hands have wrought) their essential relationship: that of the women and, by extension, the (history of the) community of Ilmorog to the land. The crops that they are growing link (all of) Ilmorog to the land. Caring for the crops with their labor is caring for the land-a deeply historicized postcolonial romanticization of Blut und Grund, in all its political difficulties, a romanticization that acknowledges the women's physical labor but cannot quite acknowledge the violence of the struggle between mortals and the earth; mortals are always subject to the climatic vagaries that emanate from the earth or the sky. The relationship amongst Munira, the women, and this instance of dwelling is grounded in a momentarily shared commitment to Bauen. As Heidegger says, to build is to "cherish and protect, to preserve and care for, specifically to till the soil, to cultivate the vine." 11

Impossible to ignore here again is how Ngugi and Heidegger, the rugged anti-colonialist (in addition to vehemently opposing its successor, neocolonialism) and the politically tainted existentialist, share the language of romanticized attachment to the land. For his part, Munira "cherishes" the relationship between mortals and the earth; to "cherish the soil" is for Heidegger a precondition for how human beings dwell - and a political sensibility. Bauen, says Heidegger, "originally means to dwell;" it means, we might say, to imagine a oneness between Ngugi's laboring women and the fecundity that emanates from their hand, as evidenced, of course, by the "green land" that they have produced.12

The crops, the "green," at once obscures the land (the crops cover the land with their plenty, a good thing for the community; it means that they have provided for themselves for yet one more season) and reifies it because it is this very bounty of the land that reaffirms the relationship amongst Bauen, Wohnen and Sein: building (sowing, weeding, reaping, preparing the soil for the next season), dwelling (being at peace in the land because of what the land and the community's labor provides; continuing to labor in the face of climatic uncertainty), and Being (dwelling in peace). Cast in such a light, it is left to Munira - appropriately, perhaps, in his role as teacher - in his observation to provoke us to think [Denken] this relationship, this web of connections that binds and sustains rural life in Ilmorog. Munira is tasked with comprehending the event, all of which turns on him naming the event, as such, without naming it an event. In his role as a Baldwinian witness, Munira has to stipulate to the occurrence of the event; 13 in James Baldwin's work the witness assumes the role of critical observer, of bearing witness to - speaking publicly, telling others - what the event is, what important occurrence is taking place within the community; ${ }^{14}$ the witness offers what might, in Michel Foucault's terms, be designated a "veridicted truth."15 
It is in Ngugi's "watching" Munira that it becomes possible to "observe" the seasonal nature of postcolonial dwelling, presented through a cycle of plenitude ("green earth"), want (long cycles of drought), and neardestitution (the economic devastation that follows because of the drought), which leads to the undoing of old Ilmorog. It is, however, more complicated than to conflate the demise of old Ilmorog with the future impossibility for dwelling. When Munira observes the oneness of the women, there is already incipient within that act of dwelling the promise of violence - the violence to come, if you will, the violence of letting-be. The women's oneness is a precarious act of being with the earth because the self-same earth that allows them, in the "Munira moment," to do so peacefully will soon threaten them, through drought, with socio-economic death. There is always, as we shall see shortly, the always already presence of violence, even in the moment of plenitude. Death, the inevitability of death as such, is what ordersknowingly or not-Ilmorog, the postcolonial world, the world itself.

Once the rural fundament of postcolonial life is destroyed, through drought, crop failure or poor retail prices for the crops, what inevitably follows is some form of capitalist rupture. (Usually, but not exclusively, this rupture takes the form of industrialization of venture capitalism that puts paid to past relationships with the earth.) The fourfold of old Ilmorog is disrupted into a dystopic landscape. Native to the act of transformation (first in the line of occurrences), often biopolitically violent, is a radical change in temporal structure. "Ilmorog" is made simultaneously unrecognizable (new constructions, new modes of economic exchange, new relationships to the land, as well as the earth, sky and divinities) and antecedent to itself.

The force of rupture renames the self through the violent addition of a "prefix" that is really an adjective ("New"). Following this logic, there is nothing to be done except divide "Ilmorog" temporally, an act utterly devoid of critical imagination as no one can conceive of an original name. Through this simple act, "old Ilmorog" is superseded by "New Ilmorog." Capitalism, as we shall see, triumphs over the bucolic past. All that remains is to provide an itinerary and itemization of what has been lost, beginning and ending with dwelling. Petals of Blood, however, complicates the transition to capitalism through autoimmunity-tragically so, because capital is only able to make inroads into Ilmorog through a combination of crisis (the drought, a condition the villagers cannot control) and traditional practices (reproducing, in response to the crisis, in order to turn things around, those goods held sacred by the past).

New Ilmorog it is, reductively phrased, best understood as the effect of old Ilmorog's inadequacies (it has no material resources to sustain when natural disasters occur) and the Kenyan state's structural indifference; Ilmorog belongs to the periphery and, as such, it suffers the fate, indifference, to which all state structures subject those who inhabit its outermost regions. In the moment that Ilmorog finds itself economically 
destitute, there is no state practice (drought relief, educational sustenance, emergency funding or food supplies) committed to meeting its wants - an "epidemic" of non-delivery. The Ilmorog villagers are, in terms Marx might recognize, a population surplus to the functioning of the state, vulnerable in the face of postcolonial state's indifference. The villagers are, as it were, no more than units of marginal economic utility.

\section{Theng-eta will save you, then it will kill your past}

Poetics...does not attempt to find a meaning but to understand the techniques that make meaning possible, techniques that belong to the generic tradition.

Jonathan Culler, Theory of the Lyric

In their attempt to save Ilmorog, the village elders, led by Nyakinyua (Wanja's grandmother), decide to brew a traditional drink, "Theng-eta." Nyakinyua leads the community in the brewing process, which she also presents as a lesson in the cultural history of Ilmorog. For Nyakinyua making the drink is a sacred practice: "Theng-eta" is a "dream. It is a wish. It gives you insight, and for those favoured by God it can make them cross the river of time and talk with their ancestors.... Only you take it with faith and purity in your hearts." 16 Initially, the drink brings relief from the drought, after which Abdulla begins to sell Theng-eta in his little shop (where Wanja still works, before her own entrepreneurial turn in New Ilmorog). As a consequence, its popularity spreads among the residents and itinerant migrant workers who pass through Ilmorog.

However, the rising popularity (and profitability, however small scale) of Theng-eta causes aspirant capitalists such as the "business tycoon" Kimeria to seize it, commercialize it, and exploit it for their gain. ${ }^{17}$ Soon enough, "Theng-eta" is taken over by a multinational corporation comprised, unsurprisingly, in part by the new postcolonial elite. Most notable among the investors are "Chui - an educationist and a businessman; Hawkins Kimeria - a business tycoon.... Mzigo - an educationist turned businessman."18 Kimeria, previously known as Nderi wa Riera before he Anglicized his name, harbors grand entrepreneurial dreams, modeled on a wide array of global capitalist dynasties. ${ }^{19}$ The new corporation, needless to say, has little or no consciousness of the drink's ancestral significance; the native "tycoons" certainly make no promises that the mass-marketed version will make it possible to "cross the river of time" or "talk with ancestors."

When Nyakinyua, assisted by Abdulla, Wanja, and Munira, make that first batch of the brew they cannot possibly know that their offering to the gods will lead in short order to the drink's popularity, to the usurpation (industrialization) of the production process and, most critically for them, 
the undoing of Ilmorog. It is thus not hyperbolic to claim that the moment the villagers brew Theng-eta they are initiating, without any consciousness of the effects they are unleashing, the end of their way of life. That decision, to reach into the past in order to secure a better present, will have catastrophic consequences both for the future of Ilmorog, which is about to pass into history, and their own individual futures.

For his part Nderi wa Riera is "convinced" that "Africa could only be respected when it had its own Rockerfellers, it's Hughes, Fords, Krupps, Mitshubishis."20 Full of capitalist hubris (the stuff of his postcolonial dreams), Nderi wa Riera seeks to take his place in this lineage of capitalist greats, beginning with the mass production of Nyakinyua's sacred drink. Nderi's dream of joining the ranks of the "Fords" and the "Krupps" is thwarted, but the consequence of his grandiosity is New Ilmorog, that "new" place where industrial production is replacing agricultural production as the primary form of economic life.

This rapid transition from one form of production to another disrupts the fourfold. In the industrialized production of Theng-eta, unlike the labor involved in farming, the earth is no longer to be "saved," nor does the earth have a special relationship to the sky or the divinities. What this new economy of capital transforms most radically is the relationship between the villagers (mortals) and the earth - what the earth no longer produces, how the earth no longer sustains peasant life. Because of industrialization, the sacred pact between Ilmorog residents and the earth is broken, a rupture that ostensibly divides the present rise and reign of capital from the past, where dwelling was at times possible. It is a rupture that divides the mortals from the "divinities."

However, this rupture appears to have been anticipated by Ndemi, who belongs to a previous generation. As such, the rupture is articulated as a dubious inheritance, an inheritance that is also a form of accountability to the earth and the past: "Ndemi left a curse. His children were never to abandon this land: they were to defend it with blood, it and all that it produces." 21 With the conversion of the land into equity (simply another asset lacking historic value except insofar as it allows for the production of Theng-eta), it can be mortgaged in the form of factories; capital dissolves the bond between, as it were, Blut und Grund), the bond between the earth and mortals has been severed. The land has been, effectively, if not "abandoned" then ceded to the force of capital; what the land, now "defenseless" against the force of capital, "produces" is an anathema, an unthinkable, something unconscionable, to Ndemi. There is no longer any reason to "defend with blood . . . all that it produces." In fact, that moment in history has arrived where Ndemi's "children" can only "defend the land" by "abandoning," forswearing (a futile gesture), that which it "produces." Is capitalism incompatible with dwelling? 
In New Ilmorog the land itself has become a source of degradation. All that remains, as we speculate as to that which we already know, is to inherit the "curse." In Petals of Blood's romantic terms (the earth as the fundament of Sein), this inheritance is the surest sign that all possibilities for dwelling have been foreclosed. The best that Ndemi can hope for, if we cast him as a divinity, is that the terms of the curse-the abrogation of a historic pact between mortals (Ilmorog villagers who have, in the scheme of postcolonial capital, little economic value) and the earth (the village itself; all its dwellings, all its spaces) - are understood; that the old residents (as the new ones are of no significance) recognize the violence being done to dwelling in the cause of an a-historic capital.

The Kenyan businessmen represent a capital impatient with the past and with dwelling as such, allowing Petals of Blood to, in Culler's terms, make obvious the "poetics" of capital. The history of capital and/in the postcolonial state is not an argument Ngugi seeks to rehearse. Instead, his novel focuses on how the "technique" of capital (figured as the most obvious sign of the West because capital "originates" in the West, or made manifest through local entrepreneurs working with-in the interests of-global capital) in the postcolonial state demonstrates capital's triumph over the state. Capital is everywhere, as likely to brand Theng-eta as a new drink as it is to expropriate natural resources of exploited local labor in Kenya or attack unions in Europe. Rather than belabor the effects of capital's ubiquity through a critical interpretation (hermeneutics), Petals of Blood attends to the "technique" (poetics) of capital. The novel shows how the logic that drives capital-accumulation, profit, branding-is at once impervious to race (capital is capital, regardless of where it extracts wealth or who produces that wealth; marginal utility describes peripheral communities in postcolonial Kenya as much as it pertains to impoverished workers living at the fringes of a major European or US city) and attentive to the opportunities provided by African independence. In this logic, capital is neither white nor black, it is simply capital and as such capital has a keen understanding of how the politics of race can be mobilized to maximize the opportunities enabled by the changing of the political guard (as in the dreams it bequeaths to Kimeria and his colleagues). Capital is ruthless. Capital does not discriminate in an institutional sense-it does not value profits from black Kenya any more than those from Germany or Korea-but it does discriminate in that it makes ruthless economic decisions about value, utility, return on investments, and so on. Capital decides where to invest, and determines when new profits should be withdrawn or reinvested.

Further, the monopoly sought and established by the black postcolonial elite in Petals of Blood is a function of the alliance between capital and the law. In fact, such is the influence of the elite that it might be impossible to distinguish capital from the law.22 The drive to "standardize production," the expedient harnessing of the traditional resonances of 
Theng-eta to the project of wide-scale marketing and distribution results in what Foucault, in his discussion of post-War German neo-liberalism, names the "point of fracture." 23

The point of fracture, what distinguishes Ilmorog from New Ilmorog can also be understood in Weberian terms:24 Nyakinyua's brewing of Thengeta marks the last (or one of the last) moments of community [Gemeinschaft] in Ilmorog. That first brewing, in which Abdulla, Wanja, Munira and others are initiated into the tradition, stands as a moment of Gemeinschaft. In this regard the standard distinction between community and society obtains. The community of Ilmorog, a series of interests and objectives that binds individuals, stands in contrast to the society, Kenya, broadly defined by a network of social relations; the community is geographically specific to Ilmorog while the society could potentially extend far beyond Kenya's borders. The community's brewing of Theng-eta serves to determine individual roles (taught by Nyakinyua), to transmit beliefs (the transcendent possibilities of the brew, if consumed properly, that is, historically) and the political values of Ilmorog. What follows from this communal act (in addition to autoimmunity), is Gesellschaft, configured here as that conjuncture where society and community might be said to meet, and where society (capital) begins to overwhelm community (the tradition of collective brewing). Gesellschaft is that "fractious point," in truth, a moment of political crisis, in which the more formal (and thus impersonal) policies of social intervention manifest, "interventionism is pursued as the historical and social condition of possibility for a market economy," and the "market economy" ensues, at the cost of the old Ilmorog. ${ }^{25}$

The rise of a "market economy," albeit one that is not in the least competitive (one of the foundational tenets of post-War German neoliberalism), transforms not only Theng-eta - how it is produced, consumed, understood, what cultural or economic "meaning," if any, attaches to it makes all but unavoidable the emergence of New Ilmorog. "This povertyand drought-stricken, depopulated wasteland" now comes complete with a highway, increased traffic, and the marginalization, yet again of course, of the inhabitants of old Ilmorog. ${ }^{26}$ No matter that for lifelong residents of the place, among whom Nyakinyua, Njuguna and Mutui number most prominently (residents who remember the time when the "land was not for buying. It was for use."), it was still simply "Ilmorog," that place where "[n]one of the promises had yet materialized. Ilmorog was still a kind of neglected outpost of the republic." 27 The contradiction of capital is fully manifest in Ilmorog. As a "neglected outpost" it was free to dwell (in moments, at least), as a site within the capitalist network (as a profitable venue) it was subject to the dictates of capital. Following its "capitalization" (investing in the community's most marketable product), Ilmorog has to conform to the demands of the society (it is now enmeshed in a set of 
multinational relations), the party (whose members seek to benefit from the investment of their capital) and the (absent, ineffective, indifferent) state.

New Ilmorog may remain "poverty- and drought-stricken," but it is now famous for being the birthplace of Theng-eta. ${ }^{28} \mathrm{New}$ Ilmorog may be unfit for dwelling, may retain its status as just another postcolonial outpost, but it is now marked by its difference-designates both a temporal and a conceptual difference, resides in -its status as a site for the proliferation of black and multinational (that is, black and white) capital; its productivity, its transformation from site of marginal utility to one of multinational investment, no matter the ongoing discrepancy between rich and poor, makes it different.

Ilmorog is, in this sense, originary. It is that place, in Petals of Blood's political imaginary, which enabled the emergence of black capital. It is this status, unwanted though it may be by Nyakinyua and those who see the world as she does (keeping the residues of the past alive, despite the threats to it by a new political dispensation), that causes politicians, the local and national business elite to descend upon Ilmorog. The history that produced Theng-eta is, in a perverse way, what makes old Ilmorog superfluous and anachronistic to itself. The old Ilmorog cannot meet the needs of capital so New Ilmorog must be brought into being. In Petals of Blood's terms, it is capital, more than the political structure of the postcolonial state (sovereignty, a new flag, a new anthem, the iconization of anti-colonial heroes, the public dreams of equality and fraternity that follows from black liberty), which marks the transition from colonial rule to black independence.

\section{“Letting Be" 29}

"You can observe a lot," as Munira does, "just by watching" the rural populace of the postcolonial nation dwell-before, that is, dwelling is threatened by the drought that leads to the capitalization of Ilmorog. Munira's watching the women in their oneness with the "green earth," resplendent, plentiful, constitutes an instance of postcolonial Africa (Kenya) "letting be." To let be is to be at peace, as the women are. To dwell, says Heidegger, is "to be set at peace . . . to remain at peace within the free, within the free, the preserve, the free sphere that safeguards each thing in its essence." 30 To let be, the women "free" to "safeguard" the earth - and "each thing" that they sow, plant, weed and reap - in its essence. To let be is to be "at peace within the free," the freedom of the land, free to tend their own land, this "free sphere" that is, in this moment, theirs in a rare moment of an Ilmorog at peace - at peace with itself, at peace with the world, "each thing" in its place, "each thing" is let be. Here "each thing" means each person, their God/gods, the earth that allows them to plant, and the sky from which the rain comes, "within the free." It is, tellingly, when the rain no longer 
comes that peace-letting be-is no longer possible because the drought ruptures the harmony - the oneness, the shared "preserve" - of the fourfold. Peace depends, in Petals of Blood, on nothing so much as the oneness - when the "essence" of "each thing" is "safeguarded" - of the fourfold. In postcolonial Africa to let be is to know dwelling as the absolute condition for a postcolonial Africa at peace; to observe postcolonial Africa at peace is to be confronted with a postcolonial Africa embracing dwelling and being embraced by, folded into, dwelling.

Under these conditions, the postcolonial becomes the act of writing for a different time, for a time other than the now (Nyayinkua looks to the past; Karega seeks a better future, narrowly conceived), a time, in Heidegger's thinking, in which it is possible to dwell; but neither the past nor the future is, as we shall see, a time without violence. The breaks and ruptures between the time desired (where Wohnen obtains) and time itself (the extant political) allow for interruption (the event): a violent disordering. Such a violent disordering, Petals of Blood's Theng-eta moment, makes of the present the time of the unheimlich (uncanny) - more than that, a time actively hostile to dwelling - that is, to Sein.

Does dwelling emerge from violence? Is such an emergence possible? What, then, given the incipient presence of violence, is the relationship between dwelling and violence? Is it, as one would expect, that (the presence of) dwelling guarantees the absence of violence? When there is dwelling, it would follow, there is peace, there is letting be? And, symmetrically, (the presence of) violence signals the impossibility of dwelling? Iterated as questions, these inquiries give voice to a set of reasonable expectations.

However, while it could be assumed that dwelling and peace are inveterately linked, and that dwelling, whether in the past (the women are at peace with the earth, the sky and the gods) or the future (as imagined by Karega: a socialist state), establishes peace, the question of violence remains obstinate in its presence. The presence of violence indicates not the absence of dwelling but the presence-the pertinence, the immanence-of the Heideggerian injunction: to think dwelling as the letting-be of all forms of economy and, as such, to think letting-be as the a/symmetrical economy of peace-violence; an economy of peace-violence, moreover, in which capital is neither destructive of or conducive to dwelling. Letting-be admits of capitalism as much as it does of any other mode of production; capitalism is thus not antithetical or inherently antagonistic to dwelling but it does, nevertheless, comprehend as such the potential violence-the force of disruption at the heart of capitalism - that capitalism is likely to bring.

The women, in this regard, are neither at peace nor at war in their dwelling, they simply let-be the two; the women let-be any form of economy. In this economy, because of the force of letting-be, neither dwelling nor violence is ever fully present or truly absent. Dwelling, more so 
than violence, is always subject to its own deconstruction; in many ways, of course, violence (in the form of capitalism or armed conflict) is the catalytic force that threatens (and may undo) dwelling.

Violence is always incipiently, irrepressibly (constitutively?) present, at work in ways both discernible and surreptitious, under or within the condition of dwelling. It is never either violence or dwelling, dwelling or violence, because such a dis-junction (an uncoupling or a dichotomy), the unyoking of one from the other, is anathema to Heidegger. Dwelling and violence, then, are both fully Heideggerian conditions in that they must be thought. It becomes possible to assert, in this vein, that in "tracing the essence of dwelling" we have not only made both dwelling and violence "worthy of questioning" and "worthy of thought" but that we have "located" one in the time of the other, that we recognize how one constitutes (to a greater or lesser extent, itself in - and through - the time of the other; 31 we have understood how to let-be. ${ }^{32}$

It is for this reason that (postcolonial) dwelling is always haunted, by the prospect, nay, the inevitability, of death. In terms of the fourfold, death might be configured as another god because it always remains other and yet it is part of all language and economy (the economy of mourning, for example). ${ }^{33}$ The ambivalence of death makes it an ideal metaphysical topic because it structures everything and everyone; Wanja and Muturi, for example, mourn the death of what is lost - communal ownership of the land, the fidelity of one Ilmorog resident to her or his Nachbar; Karega mourns the death of Deedan Kimathi and with him the impossibility of a future free from exploitation of the poor and the marginal. Death is the (inevitable, irrepressible) negativity of chronological time. There is, then, no other time for the postcolonial (or, anyone else for that matter) but death, the only extant guiding structure or teleology.

Conceived as such, it is no paradox that the very omnipresence of death makes it possible to dream of dwelling (we can only properly dwell) in the face of death. It is no contradiction that we dwell for the impossible even, especially, in the face of death. In this way it is imperative to always first think dwelling as its own, as articulating its own, deconstruction. Dwelling alludes to, it contains within itself, it demarcates, the khora (spacing), the space, the radical opening, that is the portal to death. To dwell is to know what it means to let-be, to live in, to live with, not despite, the presence of death. It is in this way that dwelling makes something "poetic" visible: dwelling enables us to "understand the techniques that make meaning possible" in the drama that is dwelling, postcolonialism and capitalism in Petals of Blood. The non-prescriptive ways in which Ngugi thinks dwelling in his novel enable us to understand how the "techniques" of letting-be work. Letting-be is not a way out of the drama that is dwelling, postcolonialism and capitalism. It is, rather, an engagement that uses the "techniques" - the meaning-making structures, if you will - of dwelling to 
think capital in its relation to dwelling and to think postcolonialism in its relation to dwelling. It is, most importantly, to think how this nexus, dwelling, postcolonialism and capitalism, might be apprehended when dwelling constitutes the point of entrée.

As such, the question is not really "What is it to dwell?," although Heidegger's query retains its historic capacity to haunt and to trouble our thinking of the postcolonial. The question is, rather, how does dwelling reorient the relationship between postcolonialism and capital? At the very least, it is because dwelling can no longer be understood as - reduced to that temporality that is coterminous with peace (the oneness of the Ilmorog women with the Kenyan earth) that new fractures between postcolonialism and capitalism become visible. And, out of these fractures emerges the more difficult, the more resistant (to resolving dwelling as a peaceful mode of existence) notion of letting-be. Thus letting-be is what emerges when dwelling, the initiation of human beings in time and space, opens into the coterminous - simultaneous - possibility of peace, violence, capitalism, socialist desire, and postcolonialism. Letting-be makes manifest the techniques of dwelling.

1 Martin Heidegger, "Building Dwelling Thinking," Martin Heidegger: Basic Writings, San Francisco: HarperCollins, 1993, 360.

${ }^{2}$ I owe this phrase to Tejumola Olaniyan. (Presented in a lecture at Cornell University, 23rd October, 2015.)

${ }^{3}$ Ngugi wa Thiong'o, Petals of Blood, London: Heinemann, 1977, 71.

${ }^{4}$ Munira is not the "Home Guard," the fifth columnist, the traitorous native informant sketched with such conceptual delicacy (Wangari the carpenter is given depth by his desire for Mumbi, wife of the Kenyatta loyalist and liberation fighter Gikonyo) in A Grain of Wheat; indeed, Munira may be, politically speaking, worse, because he is marked by nothing so much as his seemingly inexhaustible drive toward neutrality.

5 Ibid., 24.

${ }^{6}$ Heidegger, "Building Dwelling Thinking," 349.

7 The term "nostalgeric" is borrowed from the notion of "nostalgeria" that Jacques Derrida offers in Monolingualism of the Other: Or, the Prosthesis of Origin, translated by Patrick Mensah (Stanford, CA: Stanford University Press, 1998).

${ }^{8}$ Heidegger, "Building Dwelling Thinking," 349.

${ }^{9} \mathrm{lbid}$.

${ }^{10}$ Here the neologism "sharedness," which is intended to accentuate the indissoluble mutuality between Sein and bauen, might better convey what is at stake. 
${ }^{11}$ Heidegger, “Building Dwelling Thinking,” 349.

12 lbid.

13 It is also possible to conceive of Munira as a Gramscian intellectual of the traditional variety; that is, Munira as the figure of formal learning who enjoys, by virtue of that education, a certain elevated position within the community. And there is some reason to configure Munira in this way because, much as the democratic thrust of Ngugi's novel seems reluctant to admit of Munira's "elevation," the teacher retains his importance as the novel's political pivot - not everything, but many things seem to turn on him, his actions often (but not always, it is critical to recognize) set things in motion; even his inertia and his history of political neutrality functions (dialectically) in contradistinction to the political histories of figures such as Abdulla and Karega.

14 Figuring Munira as a Baldwinian witness works in this instance because of the Christian inflection it has in the Baldwin oeuvre, especially the relationship of the witness to the church, a role that obtains throughout Baldwin's career, from, say, Go Tell It On The Mountain to The Evidence of Things Not Seen, Baldwin's report on the 1979 Atlanta child murders. Like Baldwin, Munira is raised in the church; like Baldwin, Munira rejects the church from early adulthood; unlike Baldwin, who operates forever (as an adult) at a troubled, complicated, remove from the church, Munira returns to the church in search of restoring meaning to his life; as a means of overcoming his alienation from his family, nuclear and extended, Ilmorog and, perhaps most pointedly, from himself, from his sense of who he thinks he is.

15 In strictly Foucauldian terms, "veridiction" is a statement that is true according to the worldview of a particular subject; Munira, in this case, producing a regime of truth. A "veridicted truth," in this context, recognizes that the event is rendered - made legible, biopolitically visible - by Munira while also retaining to itself a certain drawing into question of that rendering; "veridiction," in Foucault's sense makes audible the possibility of an absolute truth ("veracity," is what we might hear in "veridiction"); "veridiction" rings out to the listener as bearing within it the imprimatur of "veracity" (truth) and, yet, distinctly and deliberately, it is not. This is, I would argue, intentional on Foucault's part, which is what the term so evocative and conceptually useful; "veridiction" does nothing so much as draw truth into question.

${ }^{16}$ Ngugi, Petals of Blood, 41.

17 Ibid., 44.

18 Ibid.

19 Ibid., 186.

20 Ibid.

21 lbid., 213.

22 However, as ordoliberals, most especially Wilhelm Röpke, argue, monopolies are not stable and the concentration of capital in a few hands is, contrary to what the monopolists say, not good for capitalism. The ordoliberals take their name from the journal, of the same name (ORDO), in which they published their work. Walter Eucken, Franz Böhm, Hans Grossmann-Doerth and Leonhard Miksch, in addition to Röpke, were the movement's main thinkers, comprising the Freiburg School. They were most active and influential in the period between 1930-1950. The movement included in its ranks not only economists but also political theorists who played a key role in shaping the post-War West German economy. Eucken advised Ludwig Erhard's economic advisory council on West German economic policy in the aftermath of the war, a project for 
which the Freiburg School was especially well equipped to do, given that they had been considering these questions since at least the mid-to late-1930s. The Freiburg School, like the Frankfurt School of cultural theorists, were implacably opposed to the Nazi regime and Eucken, in fact, spoke out repeatedly against the policies advocated by the Freiburg rector, Martin Heidegger. The Freiburg School is of special interest to Foucault in his study of neo-liberalism in The Birth of Biopolitics.

${ }^{23}$ Michel Foucault, The Birth of Biopolitics: Lectures at the Collége de France 1978-1979, ed. Michel Senellart, trans. by Graham Burchell (New York: Picador, 2004), 146.

${ }^{24}$ Max Weber is a key thinker for Foucault in Lectures 6-8 of The Birth of Biopolitics.

${ }^{25}$ Foucault, The Birth of Biopolitics, 160.

${ }^{26}$ Ngugi, Petals of Blood, 110.

27 Ibid., 247.

28 Ibid., 110.

${ }^{29}$ I owe this phrase to Jean Paul Martinon, who introduced me to the notion at a colloquium in June, 2015. I thank him for allowing me to use it.

30 Heidegger, “Building Dwelling Thinking," 351.

31 Ibid., 362, emphasis in the original.

${ }^{32}$ As such, in the postcolonial all time, chronologically understood, is unequal to itself; the present is, as critics, beginning with Frantz Fanon and writers such as Wole Soyinka, Chinua Achebe, Sembene Ousmane and Ngugi have insisted, unequal to itself. It is for this reason that the postcolonial is, per force, before and in itself (already) an abject project in which the time of writing recasts and recreates the abjection of time; or, as we understand it, the political failure - Ngugi's oeurre is testimony to this - that is the postcolonial.

${ }^{33}$ Mourning, of course, is an economy that predominates in the thinking of all Ngugi's main protagonists. Wanja and Abdulla (who stand, in this regard, as heirs to Nkinyua and Muturi's political lineage-responsibility to the past, to the Ilmorog of tradition) mourn what is lost; Karega, and this is immanent in his commitment to the struggle against neo-colonialism, mourns for what is not to come, what cannot be brought into being. In this regard, Karega and Munira have, surprisingly, a great deal in common: they are both in search of a salvation from the present that can only be achieved through the future; what only the future can bring. 